\title{
Transformasi dan Optimalisasi Potensi Masjid Daerah Ujung Utara Kabupaten Tasikmalaya
}

\author{
Moh. Yusup Saepuloh Jamal, Muhamad Dani Somantri, \\ \& Cecep Moch. Ramli Al-Fauzi \\ IAILM Suryalaya Tasikmalaya \\ Email: mohyusupsj@gmail.com
}

\begin{abstract}
Mosque has a pivotal role in the process of Da'wah for Muslim, including al-Barokah Mosqu, Guranteng, Tasikmalaya. This transformative research aims at transforming people's perception in understanding the substance of the role and function of mosques and optimizing the potential of the mosque to its fullest. This Participatory Action Research model links the social change process through three-area of empowerment : Community commitment, local leader, and institutional based needs. The results of the study gained action of change: Seeking the transformation of community paradigms on understanding the substance role of the mosque through several actions: FGD for restructuring DKM Management, strengthening DKM and DKM management training. Meanwhile, the second stage is to optimize the potential of the culture by implementing the mosque empowerment based on local culture, such as the training of Friday's cermon, corpes-handling management, Ziswaf Manager, reading Marbabaan, forming youth-mosque-managers, as well as assistance by other potential-based empowerment activities.
\end{abstract}

\begin{abstract}
Abstrak: Secara substansi masjid mempunyai peran sentral yang sangat penting terhadap laju perjalanan dakwah umat Islam. Peran sentral masjid kenyataannya tidak berbanding lurus dengan keberadaan masjid al-Barokah daerah ujung utara Kabupaten Tasikmalaya. Penelitian transformatif ini bertujuan untuk mentransformasi persepsi masyarakat dalam memahami substansi peran dan fungsi masjid dan mengoptimalisasikan potensi masjid secara maksimal. Penelitian ini menggunakan model participatory action research yang menghubungkan proses perubahan sosial melalui tiga pemberdayaan: komitmen masyarakat, local leader, dan institusi berdasarkan kebutuhan. Dari hasil penelitian diperoleh aksi perubahan: mengupayakan transformasi paradigma masyarakat terhadap pemahaman substansi peranan fungsi masjid yang diupayakan melalui beberapa action: refleksi FGD merestrukturisasi pengurus DKM, pengukuhan pengurus DKM; dan pelatihan manajemen DKM.Sementara tahap kedua melakukan langkah optimalisasi terhadap potensi yang dimiliki dengan menerapkan pemberdayaan masjid berbasis lokalitas budaya, seperti pelatihan
\end{abstract}


khutbah Jum'at, pengurusan jenazah, pengelola Ziswaf, membaca marhabaan, pembentukan pengurus remaja/pemuda masjid, serta dampingan kegiatan pemberdayaan lainnya berbasis potensi.

Kata Kunci: masjid, optimalisasi, potensi, transformasi.

\section{PENDAHULUAN}

Masjid mempunyai peran sentral yang sangat penting terhadap laju perjalanan dakwah umat Islam. Antara masjid dan ajaran Islam tidak dapat terpisahkan. Kedua syi'ar Islam itu saling melengkapi, tanpa adaya bangunan masjid umat Islam tidak akan mengalami perkembangan yang pesat, begitu pula sebaliknya. Fenomena demikian sangatlah wajar, karena pada awal perjalanan hijranya ke Madinah Rasulullah SAW menjadikan bangunan masjid sebagai sentral aktivitas umat generasi awal yang diposisikan sebagai integrasi fasilitas dalam bidang sosial, agama, dan negara.

Dalam risetnya, Muhammad Muhib Alwi menuliskan, sejak zaman nabi masyarakat di sekitar masjid sudah dapat mengambil manfaat dari sistem ekonomi yang berbasis masjid, yaitu melalui bauitul maal wa al-tamwil (BMT) lembaga ini menjadi salah satu institusi ekonomi yang mampu menjamin kemandirian ekonomi masjid dan sekaligus membantu pemberdayaan ekonomi masyarakat di sekitar masjid (Muhammad Muhhib Alwi 2015). Hillenbrand R. menuliskan fungsi masjid pada zaman Rasulullah SAW sebagai pusat pemerintahan, pendidikan, kegiatan sosial, ekonomi, budaya, bahkan pertahanan militer (Hillenbrand R t.th).

Lebih kompleks Quraish Shihab memaparkan, ada sepuluh keanekaragaman peran dan fungsi masjid bagi umat Islam, yaitu: tempat ibadah, tempat konsultas dan komunikasi (masalah ekonomi, sosial, dan budaya), tempat pendidikan, tempat santunan sosial, tempat latihan militer dan persiapan alatalatnya, tempat pengobatan para korban perang, tempat perdamaian dan pengadilan sengketa, aula dan tempat menerima tamu, tempat menawan tahanan perang, pusat penerangan, dan pembelaan agama (M. Quraish Shihab 1996). Masjid yang multifungsi sebagai pusat kegiatan kepemerintahan, kegiatan pendidikan, kegiatan keagamaan, kegiatan sosial, memiliki makna penggabungan etos spiritualitas dalam kegiatan kemasyarakatan. Hal ini terjadi karena kepemimpinan tunggal yang memiliki otoritas spiritual dan temporal (duniawi) yang berdasarkan kenabian dan bersumberkan pada wahyu ilahiyah (Munawir Sajdali 1993). 
Tak dapat dipungkiri memang, sekarang ini peranan dan fungsi masjid mengalami pergeseran paradigma ke arah yang lebih parsial atau semakin sempit (Nana Rukmana 2012). Bangunan masjid hanya dipergunakan untuk kegiatan formalistik ajaran kegamanaan yang diidentikan dengan makna ibadah mabdhah. Runinitas program masjid dibatasi oleh pelaksanaan shalat saja. Setelah pelaksanaan shalat, masjid menjadi sepi, kosong ditinggalkan oleh penghuninya (umat). Ketika waktu shalat tiba, maka ruangan masjid pun menjadi ramai kembali.

Fenomena ketimpangan dalam hal menempatkan fungsi masjid dialami pula oleh masjid Al-Barokah. Sebuah masjid dengan tipologi jam'i (jenis masjid umum tempat diselenggarakannya shalat Jum'at) yang berada di daerah ujung utara perbatasan kabupaten Tasikmalaya, berlokasi di dusun Cikadu desa Guranteng kecamatan Pagerageung Jawa Barat. Jarak tempuh Masjid AlBarokah ke lokasi pemerintah desa Guranteng sekitar $20 \mathrm{~km}$, dapat ditempuh dengan kendaraan 30-40 menit karena kondisi jalan yang rusak.Temuan fakta penelitian (problem of research) berawal ketika menghadiri acara silaturahmi yang diinisiasi oleh Bapak Undang, pemilik sekolah swasta SMK Citra Mandiri Guranteng. Acara tersebut diisi dengan agenda pokok dialog/musyawarah (Focus Discussion Group/FGD) antara tokoh masyarakat sedesa Guranteng terkait permasalahan penting yang dihadapi masyarakat dusun Cikadu tentang pasifnya perkembangan ajaran Islam, terutama keberadaan masjid Al-Barokah (FGD tanggal 21 Mei 2018).

Mengawali acara FGD, bapak Undang berkata, Perkembangan Islam di dusun Cikadu sangat menghawatirkan. Jika tidak ada mubaligh dari dusun lain, pasti pengajian akan diliburkan, masjid sudah tidak ada yang merawat, shalat berjama'ah sudah jarang dilakukan di masjid. Bahkan untuk khutbah Jum'at tak jarang saling mengandalkan. Lanjut beliau, Bagaimana nasib Islam di dusun Cikadu sepuluh tahun yang akan datang. Pandangan bapak Undang diperkuat dengan argumentasi bapak Eman, salah satu tokoh dusun Cikadu yang kebetulan pada waktu itu ikut hadir (wawancara dengan Bapak H. Undang tokoh Desa Guranteng).

Hasil dari FGD disepakati bahwa permasalahan dusun Cikadu hendaklah segera diatasi, dijadikan sebagai permasalahan dengan ruang lingkup tingkat desa yang harus segera diupayakan solusinya secara bersama tak terkecuali oleh seluruh tokoh masyarakat desa Guranteng. Beberapa bulan berjalan, ragam solusi yang pernah ditawarkan tokoh masyarakat desa Guranteng pada saat FGD belum ada satupun tindak lanjut konkret yang dapat dirasakan oleh masyarakat dusun Cikadu. 
Penelitian ini diharapkan sebagai metode integrasi pendampingan yang konkret dalam rangka mengupayakan tranformasi keberadaan masjid sekaligus mengoptimalkan potensi lokal yang telah dimiliki oleh masjid tersebut, diantaranya (1) mengubah paradigma masyarakat setempat bahwa bangunan masjid bukan hanya untuk pelaksanaan ibadah ritualistik semata (shalat dan pengajian) melalui penyuluhan/seminar/loka karya/pengajian terkait peran dan fungsi masjid yang ideal; (2) terbentuknya susunan kepengurusan organisasi DKM masjid Al-Barokah secara lengkap (sesuai kebutuhan) disertai gambaran tugas dan tanggung jawab (job description) yang jelas/ril; (3) bangunan masjid yang memiliki legalitas hukum, baik akta ikrar wakaf dari KUA setempat maupun izin operasional pendirian masjid dari Kemenag kabupaten Tasikmalaya; (4) dalam kegiatan ta'mirul masjid melibatkan berbagai kalangan, termasuk pembentukan pengurus ikatan remaja masjid (IRMA); (5) merintis pemberdayaan ekonomi masjid melalui potensi lokal sebagai tambahan uang kas masjid; (6) membuat alat peraga komunikasi masjid dan menyusunnya sesuai dengan tata kelola ruangan masjid; (7) masjid jami Al-Barokah dapat berkontrobusi terhadap kemajuan pendidikan anak dan ketahanan ekonomi keluarga pra sejahtera; dan (8) menjadi masjid jami Al-Barokah sebagai masjid yang sejajar-dalam hal pengelolaandengan masjid jami di dusun lainnya, bahkan mampu dijadikan sebagai masjid yang terbaik di tingkat desa Guranteng.

\section{TRANSFORMASI DAN OPTIMALISASI MASJID DALAM KAJIAN}

Riset Firman Nurgaha, berjudul Transformasi Sosial Umat Islam Berbasis Masjid (Analisis Deskriptif Fungsi Masjid Raya Ciromed Sumedang), Jurnal Balai Diklat Keagamaan Bandung, Vol. 4, No. 11, 2010 menyatakan bahwa, masjid telah menjadi channel of change sekaligus agent of change bagi masyarakat sekitar kaitannya dengan citra negatif menjadi citra positif yang dijabarkan melalui programprogram yakni mandiri, kerjasama, dan fasilitatif bagi masyarakat sekitar (change targets). Peran masjid dijabarkan melalui pengembalian fungsi dasar keberadaan masjid, yakni penyeimbang antarfungsi sosial dan fungsi ritual.

Riset Puji Astari tentang "Mengembalikan Fungsi Masjid sebagai Pusat Peradaban Masyarakat”, jurnal Ilmu Dakwah dan Pengembangan Komunitas, Vol. 9 No.1 Januari 2014, IAIN Raden Intan Lampung. Jurnal ini berpendapat bahwa untuk mengembalikan fungsi masjid sebagai pusat peradaban masyarakat dapat diupayakan dengan cara menggerakan majelis ta'lim yang ada di dalamnya, melibatkan remaja, mengadakan berbagai jenis pelatihan/seminar, menjadikan 
masjid sebagai pusat ilmu, bersinergi dengan pemerintah dan masyarakat, memberdayakan fakir miskin, dan menumbuhkan kemandirian masjid.

Riset M. Zulfa, tentang "Transformasi dan Pemberdayaan Umat Berbasis Masjid (Studi pada Masjid Nurussa'adah Salatiga)” Jurnal Inferensi, Jurnal Penelitian Sosial Keagamaan, Vol. 9 N0. 1, Juni 2015. IAIN Salatiga. Jurnal tersebut mendeskripsikan langkah-langkah transformasi dan pemberdayaan umat berbasis masjid dengan memfungsikan masjid sebagai tempat shalat, tempat kegiatan dakwah dan pendidikan, perpustakaan/taman bacaan, bimbingan dan penyuluhan, pembinaan sosial, dan pengelolaan zakat.

Riset Mukhibat tentang "Rekonstruksi Spirit harmoni melalui KPM Posdaya Berbasis Masjid di Kecamatan Pulung Kabupaten Ponorogo". Jurnal Multikultural \& Multireligius Vol. 14 No. 2, Juni Tahun 2015. STAIN Ponorogo. Jurnal tersebut mendeskripsikan guna mengetahui model pengembangan merangkai spirit harmoni kehidupan sosial keagamaan melalui KPM Tematik Posdaya berbasis masjid dengan pedekatan PAR, telah mampu menghasilkan ruang atau wadah komunikasi yang akrab dan integratif, serta mencairkan kebekuan komunikasi antar masyarakat yang berbeda, beragam dan bertikai.

Kegiatan sosial kemasyarakatan yang dipusatkan dari masjid telah menyadarkan masyarakat bahwa agama yang dianutnya terdapat hikamh-hikmah sebagai modal dan merangkai harmonisasi kehidupan. Kedua; perbedaan faham keagamaan menjadi energi positif dalam membina kerukunan, kedamaian dan kesejahteraan bersama. Dialog aksi telah memperkaya dialog teologis mereka, dengan berfungsinya masjid dalam dimensi yang sangat luas, tidak hanya fungsi ibadah dan dakwah saja tetapi juga memiliki fungsi edukasi, ekonomi, sosial, budaya, komunikasi dan informasi.

Disertasi Azis Muslim berjudul "Model Pemberdayaan Ekonomi Masyarakat Miskin Perkotaan Berbasis Tanggung jawab Sosial Masjid”, Program Sekolah Pascasarjana UIN Surakarta, tahun 2014. Hasil risetnya menjelaskan, lembaga masjid dapat menjadi sarana efektif untuk meningkatkan kesejahteraan masyarakat di lingkungan masjid jika dikelola dengan baik. Pengelolaan yang baik meliputi hubungan kemitraan yang bersifat simbiosis mutualisme antara masjid, jema'ah, dan masyarakat sekitar.

Tesis Nurul Janah berjudul "Revitalisasi Peranan Masjid di Era Modern (Studi Kasus di Kota Medan)", Program Pascasarjana UIN Sumatera Utara, tahun 2016. Dalam risetnya diungkapkan bahwa kehadiran masjid belum dapat dirasakan oleh masyarakat, maka beliau menawarkan adanya revitalisasi fungsi dan peranan masjid yang utuh, seperti fungsi ibadah, pendidikan, dakwah, ekonomi, sosial, politik, kesehatan, dan teknologi. 


\section{METODE DAN STRATEGI}

Pelaksanaan penelitian menggunakan model PAR (Participatory Action Research) tematik yang menghubungkan penelitian dalam proses perubahan sosial melalui tiga tolak ukur pemberdayaan, yaitu adanya komitmen masyarakat, local leader, dan institusi berdasarkan kebutuhan (R. Hari Adimihardja Kusnaka dan Hikmat 2003). Sementara metode penelitian yang digunakan adalah deskriptif analatif dengan pendekatan fenomenologis. Riset ini merupakan pola riset kolaboratif yang memproduksi pengetahuan berbasis lokalitas, tetapi tidak kehilangan relevansi globalitas (Agus Afandi dkk 2017). Metode yang digunakan dalam penelitian ini menggunakan model pengabdian berbasis PAR. Model pengabdian berbasis PAR ini memiliki tiga Variabel kunci yaitu, Parsipatoris, Action dan Research.

Sedangkan berdasarkan urutan metodologi kerja PAR ketiga varibel tersebut dirumuskan: research (Penelitian), tahap ini adalah merupakan tahapan penelitian tentang permasalahan-permasalahan yang dihadapi oleh masyarakat, permasalahan tersebut dipahami sedemikian mendalam dan mendetail, sehingga masalah tersebut bisa diketahui dengan jelas sebab dan akibatnya. Action (aksi), setelah mengetahui masalah-maslah tersebut secara mendalam dan mendetail, barulah masuk langkah yang kedua yaitu pencarian alternatif jalan keluar memecahkan masalah tersebut, yang kemudian diterjemahkan kedalam beberapa item program kerja yang akan dilaksanakan. Partisipatory, artinya dengan melibatkan seluruh komponen masyarakat dalam melakukan identifikasi masalah serta teknik pemecahannya secara bersama-sama (R. Hari Adimihardja Kusnaka dan Hikmat 2003).

Strategi pelaksanaan adalah serangkaian upaya nyata yang dilakukan oleh tim pengabdian berbasis riset/ penelitian trasformatif untuk mewujudkan terealisasinya kondisi harapan. Strategi pelaksanaan yang dimaksud diantaranya adalah: transek, observasi lapangan, wawancara, silaturrahmi, dokumentasi, FGD rencana pembentukan, dan partisipasi pendampingan masyarakat.Untuk memperoleh pedoman merealisasikan kondisi yang diharapkan dalam pengabdian berbasis riset/ penelitian trasformatif, Tim Peneliti telah melakukan rancangan pola fikir/kerangka pemikiran yang disebut dengan asumsi. Asumsi yang dijadikan sebagai acuan dalam kegiatan pengabdian berbasis riset/ penelitian trasformatif diantaranya: Pertama, Jika pengurus masjid berikut masyarakat sekitar memiliki cara pandang yang komprehensif tentang kedudukan masjid, maka pengurus masjid berikut masyarakat sekitar mampu mengelola masjid dengan baik, sehingga ketidakseimbangan cara pandang jamaah menjadi lebih rendah dan dapat diminimalisir; Kedua, Jika masyarakat 
berperan secara maksimal maka fungsi masjid tidak hanya sebagai pusat ibadah tetapi juga sebagai pusat muamalah; Ketiga, Jika sudah terbentuknya lembaga dana umat, maka masyarakat sekitar masjid bisa lebih memanfaatkannya, sehingga penyaluran dana umat tersebut bisa optimal; Keempat, Jika Pengurus masjid mengupayakan peningkatan pengetahuan dan manajemen pengurus terhadap fungsi masjid, maka pengurus masjid memiliki cara pandang yang seimbang antara masjid sebagai tempat ibadah dan masjid sebagai pusat muamalah.

\section{HASIL DAN PEMBAHASAN}

Dusun Cikadu merupakan salah satu dari dusun di wilayahdesa Guranteng kecamtan Pagerageung yang tererletak di ujung utara kabupaten Tasikmalaya, berbatasan dengan Kabupaten Ciamis. Kondisi geografis dusun Cikadu yaitu pegunungan dan lembah dari kawasan kaki Gunung Cakra Buana. Ada dua hal yang identik dengan dusun Cikadu: pertama adalah dusun penghasil susu Sapi. Hal ini di karenakan mayoritas masyarakat kampung ini merupakan peternak Sapi Perah. Sehingga daerah Cikadu merupakan salah satu sentral penghasil susu Sapi terbesar di Tasik Utara. Ada sekitar lebih dari 500 ekor Sapi perah yang di ada di kampung Cikadu, baik itu milik masyarakat sendiri ataupun milik pengusaha dengan sistem bagi hasil. Setiap hari kurang lebih 1500 liter susu murni di hasilkan di daerah in. Kedua dusun Cikadu merupakan hulu dari salah satu sungai terbesar di Jawa Barat yaitu sungai Citanduy sehingga nama dusun Cikadu desa Guranteng identik dengan nama Hulu Sungai Citanduy dusun Cikadu mempunyai luas wilayah seluas 15 hektar.

Demografi dusun Cikadu terdiri dari 3 RT dan satu RW dengan jumlah penduduk 467 Jiwa atau 136 KK.Keadaan ekonomi dusun Cikadu bermata pencaharian sebagai peternak sapi perah baik itu sebagai pemilik ternak maupun sebagai buruh ternak. selain itu karena daerah dusun Cikadu merupakan daerah pegunungan maka selain beternak masyarakat juga melakukan kegiatan perekonomian yang berhubungan dengan pertanian.

Hal pertama yang bisa dilihat dalam perubahan pengelolaan masjid Dusun Cikadu berupa transformasi persepsi publik terhadap masjid. Transformasi persepsi publik adalah upaya terstruktur yang dilakukan dalam rangka melakukan trasformasi/ perubahan paradigma masyarakat dusun Cikadu untukmemahami substansi peran dan fungsi masjid. Bangunan masjid tidak hanya diposisikan sebagai tempat ibadah ritual semata (shalat, baca al-Quran, dan ibadah mabdhah lainnya) tetapi juga sebagai fasilitas dalam rangka memakmurkan kesejahteraan 
umat/pengurus DKM/jema'ah/tetangga masjid/ dan komponen lainnya yang memiliki keterkaitan dengan institusi masjid.

Hal itu menjadi faktor pertimbangan untuk kemudian melakukan rancangan aksi pemecahan masalah melalui beberapa langkah strategis-sistemik. Pertama, FGD dan Refleksi. Pada tanggal 06 Oktober 2018 Tim Peneliti Transformatif berangkat untuk melakukan observasi, tempat yang pertama kami tuju adalah bangunan masjid Al-Barokah dusun Cikadu. Menjelang adzan Maghrib kami sampai di lokasi penelitian dan langsung persiapan untuk melaksanakan shalat Maghrib berjama'ah di masjid Al-Barokah. Ada hal yang tentunya menjadi pusat perhatian kami, yakni jumlah warga yang ikut berjama'ah kurang dari seperempat dari jumlah penduduk keseluruhan,dapat dihitung jari hanya 10 orang, terdiri dari: imam, 6 makmum orang tua dan 3 makmum lainnya adalah anak-anak.Sebuah bangunan mesjid yang disebut-sebut sebagai masjid pusat kampung (jami), namun tingkat kesadaran penduduk untuk melaksanakan shalat berjama'ah di masjid masih relatif kurang.

Berdasakan hasil FGD terkait informasi seputar situasi dan kondisi keberadaan masjid jami Al-Barokah, maka kamipun melakukan refleksi tentang pola pendampingan solusi alternatif atas problematika/masalah yang sedang dihadapi oleh masyarakat dusun Cikadu, khususnya eksistensi masjid AlBarokah.Menurut kami, tindakan/aksi prioritas yang harus segera mungkin direalisasikan adalah membenahi sistem dan model kepengurusan DKM AlBarokah.Dikarenakan jumlah kuorum yang hadir belum memenuhi representatif dari keseluruhan warga, maka pelaksanaan restrkturisasi pengurus DKM AlBarokah sepakat diagendakan satu minggu yang akan datang, tepatnya tanggal 13 Oktober 2018. Dengan catatan harus ada pengumuman, sosialisasi, undangan, dan konfirmasi terlebih kepada warga yang tidak hadir.

Kedua, Restrukturisasi Pengurus DKM. Sesuai dengan ketentuan waktu yang telah disepakati bersama, pada tanggal 13 Oktober 2018 tepatnya pukul 18.30 WIB (sesudah shalat Maghrib berjama'ah) masyarakat Dusun Cikadu menggelar kegiatan FGD (musyawarah) dengan agenda kegiatan membentuk anggota pengurus DKM Al-Barokah. Tampak antusiasme masyarakat (jema'ah masjid) yang hadir lebih banyak dibandingkan dengan pertemuan sebelumnya. Jema'ah yang ikut hadir terdiri dari beberapa unsur masyarakat setempat, diantaranya Kadus, RT, RW, tokoh masyarakat, tokoh agama, tokoh pemuda, kader, remaja, dan anak-anak.

Kegiatan, sistem, mekanisme, dan teknis pembentukan pengurus DKM dipandu langsung oleh Tim Peneliti Transformatif, targget capaian (output) yang diharapkan dari pertemuan musyawarah tersebut adalah: terbentuknya anggota 
pengurus baru DKM masjid Al-Barokah yang lengkap sesuai dengan kebutuhan dan kemampuan masyarakat Cikadu; memiliki visi misi, program kerja, dan AD/ART DKM masjid Al-Barokah yang tersusun, jelas dan terarah;menyusun rencana program kerja dari pengurus baru DKM Al-Barokah yang dapat diwakili oleh setiap seksi/bidang; dan tindak lanjut berupa usulan pelantikan/pengukuhan pengurus baru DKM Al-Barokah oleh pihak yang berwenang.

Setelah anggota kepengurusan DKM baru terbentuk secara musyawarah mufakat, kemudian dilanjutkan dengan musyawarah rencana program kerja pengurus DKM terpilih, terutama program-program yang akan direalisasikan oleh setiap seksi/bidang. Teknis penyusunan rencana kerja dilakukan secara halaqah (berembug/ngariung), setiap seksi/bidang berhak mengajukan rencana kerja jangka pendekuntuk dapat disepakati oleh forum. Jenis rencana kerja yang sudah disepakati bersama menjadi bahanrancangan program prioritas/fokus yang akan ditindaklanjuti oleh Tim Peneliti Transformatif. Diantara rencana kerja DKM Al-Barokah yang sudah disepakati adalah pelantikan pengurus DKM terpilih oleh pihak pemerintah desa, pelatihan manajemen pengelolaan masjid, pelatihan khutbah Jum'at, pelatihan pengurusan Jenazah/mayit, pelatihan sekaligus pembentukan pengurus ZISWAF DKM Al-Barokah, dan program-program pemberdayaan potensi lokal berbasis masjid.

Untuk memberikan legalitas hukum yang kuat terhadap pengurus DKM Al-Barokah yang baru, maka acara musyawarah dilanjutkan dengan perencanaan teknis danwaktu pengukuhan sekaligus pelantikan pengurus DKM terpilih yang akan diusulkan kepada pemerintah desa Guranteng agar dapat menerbitkan SK anggota pengurus DKM Al-Barokah masa khidmat 2018-2023.

Dari keberhasilan transformasi diatas, dilanjutkan dengan upaya Optimalisasi Lokalitas Potensi Masjid. Optimalisasi potensi masjid adalah upaya konkret secara terstruktur/sistemik yang dilakukan dalam rangka memanfaatkan sumber daya secara maksimal berupakelebihan/ potensi yang dimiliki masjid. Menurut riset Asep Nuryanto, sumber daya yang menjadi potensi masjid meliputi sumber saya insani (SDM), sumber daya yang bersifat fisik (tangible), dan sumber daya yang bersifat non-fisik (intangible) (Asep Suryanto dan Asep Saepulloh 2016). Disamping itu, masjid juga memiliki potensi sumber daya yang bersifat fisik, yaitu: tanah dan bangunan masjid yang mayoritas merupakan harta wakaf/hibah dari masyarakat muslimin, dana masjid yang cukup besar, dimana dana tersebut terhimpun dari berbagai sumber pendapatan yang bersifat kontinuitas seperti infak, sedekah, wakaf, dan zakat. Sementara sumber daya non-fisik masjid adalah potensi masjid yang tidak dapat terlihat dalam neraca 
keuangan, dan organisasi, misalnya teknologi, inovasi, reputasi, potensi sosial, potensi spiritual, dan potensi intelektual.

Konsep tersebut tentu menjadi target Tim Peneliti Tranformatif dalam merencanakan program pendampingan optimalisasi potensi masjid. Sementara fokus utama perhatian dititikberatkan pada potensi lokal yang menjadi ciri khas DKM Al-Barokah. Optimalisasi potensi mesjid berbasis lokalitas dijadikan sebagai kerangka acuan kami dalam merancang program-program berdasarkan pada prinsip skala prioritas. Prinsip skala prioritas diterapkan atas pertimbangan saran, masukan, dan gagasan warga yang disampaikan dalam musyawarah/FGD serta urgensi tingkat kebutuhan warga Dusun Cikadu, terutama yang berkaitan dengan pembekalan kompetensianggota pengurus DKM Al-Barokah.

Dari hasil musyawarah, maka disepakati beberapa agenda program pelatihan kecakapan sosial keagamaan. Pertama, Pelatihan Khatib dan Khutbah Jum'at. Realisasi pendampingan program optimalisasi potensi masjid yang pertama adalah menyelenggarakan pelatihan khatib dan khutbah Jum'at yang dilaksanakan pada tanggal 28 Oktober 2018 bertempat di masjid AlBarokahdusun Cikadu. Kegiatan pelatihan tersebut diikuti dan dihadiri oleh hampir seluruh anggota pengurus DKM Al-Barokah terpilih, termasuk hadir juga diantaranya dari kalangan karang taruna/pemuda/remaja aktivis masjid.

Penyelenggaraan pelatihan khutbah menjadi program utama karena dilatarbelakangi dengan beberapa alasan, yaitu: Pertama, keterbatasan jumlah khatib dan imam,DKM Al-Barokah hanya memiliki dua khatib (Ust. Uu Taryono dan Aj. Eman) shalat Jum'at yang selalu diroling dua minggu sekali tanpa ada yang menyelanginya. Karena masyarakat Dusun Cikadu tidak ada yang berani tampil untuk menjadi khatib/ imam dalam shalat Jum'at. Bahkan pernah terjadi suatu ketika kedua petugas khatib itu ada acara di keluar kampung, jema'ah shalat Jum'at saling tunjuk untuk menjadi khatib dan imam, shalat Jum'at hampir saja tidak jadi/bubar (Wawancara dengan Engkos Koswara Kepala Dusun Cikadu tanggal 13 Oktober 2018).

Kedua, Dusun Cikadu memiliki anak muda/karang taruna yang sangat berpotensi sebagai kader generasi (upaya kaderisasi) orang tuanya. Ada beberapa pemuda yang memiliki keinginan untuk menjadi khatib/imam shalat jum'at tetapi mereka tidak memiliki pengetahuan tentang tatacara pelaksanaan khutbah dan imam shalat Jum'at baik secara teoritis maupun praktis. Ketiga, adanya permohonan dari ustad yang sudah terbiasa menjadi khatib dan imam shalat Jum'at, terlebih Ustad Eman dan Uu Taryono untuk memberikan pencerahan kembali tentang kaifiyah menjadi khatib dan imam shalat Jum'at. Karena menurut pengakuan mereka, pengatahuan seputar kaifiyah shalat Jum'at masih 
belum luas dan butuh penjelasan lagi terutama pada hal-hal yang bersifat khilafiyah pendapat para ulama fikih (Wawancara dengan Ustad Eman tokoh agama tanggal 13 Oktober 2018).

Pelaksanaan pelatihan khutbah dan imam shalat Jum'at yang diarahkan pada aspek praktis langsung kepada para jema'ah terutama bagi warga yang telah menyatakan kesediannya menjadi calon khatib dan imam shalat Jum'at dengan target pencapaian sebagi berikut: meningkatnya pemahaman warga dusun Cikadu, terutama pengurus DKM Al-Barokah terpilih tentang tata cara shalat Jum'at baik teori maupun praktik; bertambahnya jumlah petugas khatib dan imam shalat jum'at, paling tidak rollingnya satu bulan sekali; dan terbentuk jadwal petugas tetap untuk mengisi posisi khatib, muraqi, dan muadrin shalat jum'at yang tersusun satu minggu sekali.

Program kedua, Pelatihan Pengurusan Jenazah. Salah satu permasalahan lain yang menjadi fokus perhatian Tim Peneliti Transformatif adalah agenda program pelatihan pengurusan jenazah/mayit, mulai dari cara memandikan, mengkafani, menshalatkan, dan menguburkan jenazah. Program tersebut kami anggap sangat urgen didasarkan atas alasan, yaitu: Pertama, seluruh masyarakat dusun Cikadu tidak ada satu pun yang pernah mengikuti pendidikan di pondok pesantren (pengalaman mondok), sehingga mereka merasa awam dalam aspek keilmuan agama, termasuk pengetahuan tentang pengurusan jenazah. Tradisi yang sering dilakukan ketika ada warga yang meninggal adalah meminta bantuan kepada tokoh agama kampung sebelah (dusun Picung) untuk memimpin pengurusan jenazah (Wawancara dengan Ustad Eman tokoh agama dusun Cikadu tanggal 01 November 2018). Kedua, adanya kebiasaan yang sering dipraktikan oleh warga dusun Cikadu ketika ada warga yang meninggal dunia kebanyakan warga hanya berkumpul di tempat penguburan/ makam saja. Sementara orang yang ikut membantu memandikan, mengkafani, dan menshalatkan jenazah sangat terbatas (Wawancara dengan Keta RT 01 Dusun Cikadu tanggal 01 November 2018).

Adapun target pencapaian kami yang diharapkan dalam kegiatan pelatihan pengurusan jenazah adalah: warga dusun Cikadu memiliki pengetahuan yang mapan baik secara teori maupun praktik tentang pengurusan jenazah mulai dari memandikan, mengkafani, menshalatkan, sampai pada penguburan; bertambahnya jumlah petugas yang ikut berpartisipasi dalam mengurus jenazah (terutama warga yang terlibat aktif dalam kepengurusan DKM Al-Barokah), seperti petugas yang memandikan jenazah laki-laki dan jenazah perempuan, petugas yang mengkafani jenazah laki-laki dan jenazah perempuan; meningkatnya partisipasi warga dalam keseluruhan kegiatan pengurusan jenazah; 
dan serangkaian kegiatan pengurusan jenazah bisa ditangani oleh masyarakat dusun Cikadu sendiri (memiliki kemandirian), tidak lagi bergantung sepenuhnya kepada petugas daridaerah lain.

Program ketiga, Pelatihan Manajemen PengelolaanZiswaf. Selain dari pelatihan pengurusan jenazah,aspek potensi DKM Al-Barokah lain yang menjadi fokus perhatian dan juga target realisasi Tim Peneliti Trasformatif adalah penyelenggaraan pelatihan manajemen pengelolaan zakat, infak, dan shadakah (Ziswaf) bagi para anggota pengurus DKM Al-Barokah terpilih masa khidmat 2018-2023.Pelatihan tersebut menjadi sangat penting karena menurut informasi dan data profil kependudukan menyebutkan bahwa secara ekonomi kehidupan mayoritas warga Dusun Cikadu sudah termasuk dalam tingkat menengah, ketahanan ekonomi keluarga sudah stabil dan sejahtera. Namun dari aspek pemahaman terhadap ajaran agama termasuk diantaranya tingkat kesadaran masyarakat terhadap kepedulian sosial keagamaan (infak, shadakah, dan zakat) masih sangat rendah. Hal itu terbukti ketika kami tanyakan kepada pihak yang mengurus keuangan DKM Al-Barokah tentang kondisi keuangan/kas masjid ternyata kas masjid kosong/tidak memiliki saldo (Wawancara dengan Agus Herna, Bendahara DKM Al-Barokah dusun Cikadu tanggal 03 November 2018).

Dengan mengkaji dan memperhatikan potensi yang tersedia, maka pada tanggal 10 November 2018 diselenggarakan pelatihan manajemen pengelolaan Ziswaf bagi para pengurus DKM Al-Barokah terpilih, dengan penyampaian materi oleh Ketua Baznas Kecamatan Pagerageung, KH. Endang Davied, dan Ketua Baznas Desa Guranteng, KH. Dayat Hidayat, bertempat di ruang masjid Al-Barokah. Dengan adanya pelatihan manajemen pengelolaan Ziswaf diharapkan dapat merealisasikan target program yakni meningkatnya kesejahteraan masjid DKM Al-Barokahyang ditandai dengan indikator berikut: pengurus DKM Al-Barokah terpilih, terutama bendahara masjiddapat memahami mekanisme pengelolaan keuangan (laporan pemasukan dan pengeluaran) yang langsung dipraktikan dalam mengelola keuangan DKM AlBarokah; meningkatnya kesadaran masyarakat dusun Cikadu untuk memberikan sebagian hartanya baik melalui zakat, wakaf, infak, dan sedekah kepada DKM Al-Barokah; meningkatnya jumlah pemasukan keuangan pada kas DKM AlBarokah secara teratur tanpa terlebih dahulu menunggu pengajuan fasilitas masjid yang dibutuhkan; kas keuangan DKM Al-Barokah yang sudah terkumpul tidak hanya digunakan sebagai keperluan masjid semata, tetapi dapat dialokasikan untuk kebutuhan sosial keagamaan, seperti pendidikan, kesehatan, ekonomi, dan pembangunan fasilitas umum;terbentuknya pengurus harianbadan 
pengelola Ziswaf (ketua, bendahara, sekretaris, dan anggota) yang kedudukan hukumnya berada di bawah pengelolaan, pemantauan, dan kebijakan pengurus DKM Al-Barokah.

Setelah pengurus DKM Al-Barokahter bentuk, ada usulan warga untuk memberlakukan kembali pola sedekah dari penghasilan penjualan susu Sapi murni, setiap penjualan susu murni diharapkan ada kontribusinya untuk kas DKM Al-Barokah satu liter susu murni yang terjual infaknya Rp. 500,-. Apabila diakumulasi dalam satu hari penjualan susu murni warga paling sedikit 100 liter, maka besaran infak yang harus dikeluarkan adalah Rp. 50.000,-/ hari dan langsung dimasukan ke kas DKM Al-Barokah. Jika kegiatan itu konsisten dipraktikan setiap hari, maka dalam jangka waktu sebulan kas DKM AlBarokahakan menerima uang pemasukan rutin sebesar RP. 1.500.000,-.

\section{KESIMPULAN}

Pelaksanaan pengabdian yang berkaitan dengan transformasi paradigma masyarakat Dusun Cikadu Desa Guranteng (transformasi persepsi publik) terhadap pemahaman substansi peranan fungsi dan kedudukan masjid dalam ajaran Islam yang kemudian diupayakan melalui beberapa tahapan sistemik (action), yakni refleksi/ FGD bersama untuk menemukan masalah, merestrukturisasi pengurus DKM secara musyawarah mufakat, pelantikan/ pengukuhan pengurus DKM Al-Barokah terpilih oleh pemerintah desa Guranteng; dan pelatihan pengelolaan manajemen DKM khususnya bagi pengurus DKM Al-Barokah Dusun Cikadu.

Sementara tahapan kedua dari pengabdian berbasis riset/penelitian trasformasi melakukan langkah optimalisasi terhadap potensi yang dimiliki oleh masjid Al-Barokah Dusun Cikadu dengan menerapkan metode pemberdayaan masjid berbasis lokalitas budaya, seperti praktikum pelatihan khutbah Jum'at, praktikum pelatihan pengurusan jenazah, praktikum pelatihan manajemen pengelola Ziswaf, praktikum pelatihan membaca al-Barjanji/marbabaan, penyuluhan sekaligus pembentukan pengurus remaja/pemuda masjid DKM AlBarokah Dusun Cikadu, serta dampingan kegiatan pemberdayaan potensi lokal berbasis masjid.

\section{DAFTAR PUSTAKA}

Adimihardja Kusnaka Hikmat. 2003. Partisipatori Research, Pengabdian dan Pemberdayaan Masyarakat. Bandung: Humaniora. 
AfandiAgus dkk.2017. Modul Riset Transformatif. Sidoarjo: Dwiputra Pustaka Jaya.

Asep Suryanto dan Asep Saepulloh. 2016. Optimalisasi Fungsi dan Potensi Masjid: Model Pemberdayaan Ekonomi Masyarakat Berbasis Masjid di Kota Tasikmalaya. Jurnal Iqtishoduna: 8(2).

Puji Astari.2014. Mengembalikan Fungsi Masjid sebagai Pusat Peradaban Masyarakat, Jurnal Ilmu Dakwah dan Pengembangan Komunitas, IAIN Raden Intan Lampung: 9(1).

Hillenbrand R., Masjid In The Centre Islamic Land, British: Brill Academic Publisher, t.th.

https://id.m.wikipedia.org/wiki/masjid. Diakses pada hari Sabtu tanggal 21 April 2018.

Nurul Janah. 2016.Revitalisasi Peranan Masjid di Era Modern (Studi Kasus di Kota Medan). Program Pascasarjana UIN Sumatera Utara.

Jauhar Fuad dkk. Pemberdayaan Anak Jalanan Berbasis Musala Di Kelurahan Ngadirejo Kota Kediri. Kompilasi Hasil Penelitian Partipatoris.

Syamsul Kurniawan. 2014. Jurnal Khatulistiwa. Jurnal of Islamic Studies. Masjid dalam Sejarah Lintas Islam 4 (2).

Muhammad Muhhib Alwi. 2015. Optimalisasi Fungsi Masjid dalam Pemberdayaan Ekonomi Masyarakat. Jurnal Al-Tatwir 2 (1).

Mukhibat. 2015. Rekonstruksi Spirit harmoni melalui KPM Posdaya Berbasis Masjid di Kecamatan Pulung Kabupaten Ponorogo. Jurnal Multikultural \& Multireligius $14(2)$.

Firman Nugraha. 2014.Transformasi Sosial Umat Islam Berbasis Masjid (Analisis Deskriptif Fungsi Masjid Raya Ciromed Sumedang). Jurnal Balai Diklat Keagamaan Bandung 11 (4). 
Nana Rukmana.2012.Masjid dan Dakwah; Merencanakan, Membangun, dan Mengelola Masjid, Mengemas Substansi Dakwah, Upaya Pemecahan Krisis Moral dan Spiritual. Jakarta: al-Mawardi Prima.

M. Quraish Shihab.1996. Wawasan al-Quran, Tafsir Maudu'i Atas Berbagai Persoalan Umat. Bandung: Mizan.

Amin Syukur. 2007. Pengantar Studi Islam, Semarang: CV Bima Sakti. 2003.

Efendi Hariandja Marihot. Manajemen Sumber Daya Manusia.Jakarta: Gramedia Widiasarana Indonesia.

Asep Usman Ismail. 2010. Manajemen Masjid. Bandung: Angkasa.

Wawancara dengan Ade Nani Tokoh pemuda dusunCikadu pada tanggal 15 November 2018.

Wawancara dengan Agus Herna Bendahara DKM tanggal 03 November 2018.

Wawancara dengan Dudu dusun Cikadu tanggal 15 November 2018.

Wawancara dengan Engkos Koswara Kepala dusunCikadu tanggal 13 Oktober 2018.

Wawancara dengan Ibu Iis Kusmatyanti Ketua BKMM Desa Guranteng tanggal 03 November 2018.

Wawancara dengan Ibu Aisyah Ketua BKMMdusunCikadu tanggal 05 November 2018.

Wawancara dengan Pak RT 01dusunCikadu tanggal 01 November 2018.

Wawancara dengan ustad Yaya Hidayattokoh agama tanggal 13 Januari 2018.

Wawancara dengan Uu Taryono tokoh agama dusunCikadu tanggal 13 Oktober 2018.

Wawancara dengan Ustad Eman S. tokoh agama tanggal 02 Oktober 2018. 
Wawancara dengan bapak Emod mantan kepala dusun Cikadu tanggal 22 April 2018. 